DOI https://doi.org/10.18551/rjoas.2018-11.46

\title{
ERYTHROCYTE MICRONUCLEI DESCRIPTION OF TILAPIA FISH IN SUNGAI WANGI WATERS, INDONESIA
}

\author{
Mardika Hanisya Putri Kania*, Herawati Endang Yuli, Zakiyah Umi \\ Faculty of Fisheries and Marine Sciences, University of Brawijaya, Indonesia \\ *E-mail: hanisyaputri@gmail.com
}

\begin{abstract}
An increase in industrial and human activities results in another increase in the amount of domestic and industrial waste dumped to Sungai Wangi, a river located in Beji, Pasuruan Municipality, East Java. It is predicted that the waste contains accumulated heavy metals that cause damage to the river and living organisms in and around the river. One of the living organisms prone to the damage is tilapia fish. This fish is considered as an indicator of environmental damage taking place in Sungai Wangi. Its hematological profile (erythrocyte, hematocrit, total leukocyte and micronuclei) helps identifying how polluted the river is. Objective of this study is to describe environmental parameter score, heavy metal content in tilapia fish (Oreochromis sp) gills and liver and hematological parameter score (erythrocyte, hematocrit, total leukocyte and micronuclei). The findings stated that the amount $\mathrm{Pb}$ and $\mathrm{Cd}$ found on the tilapia fish gills and liver has exceeded the normal threshold while the percentage of micronuclei is between 3.12 and $15.60 \%$. At last, the heavy metal causes several erythrocyte micronuclei damage.
\end{abstract}

\section{KEY WORDS}

Micronuclei, erythrocytes, Oreochromis sp., Wangi River.

Human activities and rapid development are resulting in increasing amount of water pollutant. Foreign object dumped into the water, an example of water pollution, may cause accumulation into the water, substrate and living organism in the water. Javed, et.al (2016), reported that the freshwater or river can potentially be affected by anthropogenic and xenobiotic activities (heavy metals and pesticides). This condition is deteriorating quality of water in several rivers located in the city. One of them is Sungai Wangi, a river located in Wangi village, Beji, Pasuruan Municipality, Indonesia. Adam and Maftuch (2015) stated that Sungai Wangi is prone to heavy metal contamination because domestic, industrial and agricultural waste from Sungai Prigen to Bangil is flowing to Sungai Wangi. As the result, heavy metals are accumulated in Sungai Wangi and causes health damage to living organisms in and around the river, including fish.

Heavy metal contamination causes some changes in fish hematological response. Seriani, et al (2015) reported that blood characteristics are the most suitable indicator for health condition of vertebrae, more particularly that of fish. Grant (2015) mentioned that one method to observe blood of stressful and metal-contaminated fish is to analyze erythrocyte micronuclei of the fish.

There are a lot of previous studies discussing heavy metal-contaminated water in a controlled environment. However, very few discussed hematological profile of heavy metalcontaminated fish in Sungai Wangi, Beji, Pasuruan Municipality. Therefore, the researchers are interested in running an analysis on $\mathrm{Pb}$ and $\mathrm{Cd}$, two types of heavy metal, found in Sungai Wangi and their impact towards fish based on erythrocyte micronuclei response of the fish.

\section{METHODS OF RESEARCH}

The study was conducted on October, 2016, in Sungai Wangi, Bujeng village, Beji subdistrict, Pasuruan, East Java. Observations were conducted in 4 stations. Station 1 was located in an industrial area, station 2 and 3 were located in residential area while station 4 is 
in agricultural area. Two bamboo cages (keramba) were placed in every station and these cages were submerged under water. Each bamboo cage consisted of 10 to 20 tilapia fish (Oreochromis niloticus). The following procedures were to observe environmental parameters, take blood samples for erythrocyte micronuclei detection and conduct descriptive analysis.

\section{RESULTS AND DISCUSSION}

Table 1 and 2 showed the quality of water in the 4 stations in Sungai Wangi in the beginning and at the end of the study. The data were average of samples obtained in the beginning and at the end of the study (10 days) and standard deviation.

Table 1 - Quality of Water in the Beginning of the Study

\begin{tabular}{|l|c|c|c|c|}
\hline \multirow{2}{*}{ Parameter } & \multicolumn{4}{c|}{ Station } \\
\cline { 2 - 5 } & 1 & 2 & 3 & 4 \\
\hline Temperature $\left({ }^{\circ} \mathrm{C}\right)$ & $28.07 \pm 0.84$ & $28.63 \pm 0.35$ & $28.73 \pm 0.55$ & $28.73 \pm 0.64$ \\
\hline Velocity $(\mathrm{m} / \mathrm{s})$ & $25.00 \pm 5$ & $20.00 \pm 5$ & $20.00 \pm 2.89$ & $26.67 \pm 2.89$ \\
\hline $\mathrm{DO}(\mathrm{mg} / \mathrm{L})$ & $7.55 \pm 0.34$ & $7.49 \pm 0.21$ & $7.49 \pm 0.10$ & $7.46 \pm 0.15$ \\
\hline $\mathrm{COD}(\mathrm{mg} / \mathrm{L})$ & $39.33 \pm 6.35$ & $39.67 \pm 3.21$ & $39.67 \pm 5$ & $41.33 \pm 3.79$ \\
\hline $\mathrm{BOD}(\mathrm{mg} / \mathrm{L})$ & $30.33 \pm 5.86$ & $36.33 \pm 4.16$ & $36.33 \pm 1.15$ & $66.67 \pm 2.52$ \\
\hline $\mathrm{pH}$ & $6.84 \pm 0.33$ & $7.00 \pm 0.20$ & $7.00 \pm 0.23$ & $6.78 \pm 0.32$ \\
\hline $\mathrm{Pb}$ (water) (mg/L) & $0.0173 \pm 0.0035$ & $0.017 \pm 0.0026$ & $0.017 \pm 0.006$ & $0.021 \pm 0.0036$ \\
\hline $\mathrm{Pb}$ (sediment) $(\mathrm{mg} / \mathrm{L})$ & $0.0993 \pm 0.0067$ & $0.1147 \pm 0.0025$ & $0.1147 \pm 0.0214$ & $0.0827 \pm 0.0055$ \\
\hline $\mathrm{Hg}$ (water) $(\mathrm{mg} / \mathrm{L})$ & $0.007 \pm 0.002$ & $0.0067 \pm 0.004$ & $0.0067 \pm 0$ & $0.0057 \pm 0.0015$ \\
\hline $\mathrm{Hg}$ (sediment) $(\mathrm{mg} / \mathrm{L})$ & $0.1350 \pm 0.0106$ & $0.0887 \pm 0.011$ & $0.0887 \pm 0.0199$ & $0.1063 \pm 0.0206$ \\
\hline $\mathrm{Cd}$ (water) $(\mathrm{mg} / \mathrm{L})$ & $0.0050 \pm 0.0026$ & $0.0050 \pm 0.001$ & $0.0050 \pm 0.0012$ & $0.0063 \pm 0.0006$ \\
\hline $\mathrm{Cd}$ (sediment) $(\mathrm{mg} / \mathrm{L})$ & $0.0323 \pm 0.0117$ & $0.0303 \pm 0.0075$ & $0.0303 \pm 0.008$ & $0.0550 \pm 0.005$ \\
\hline
\end{tabular}

Table 2 - Quality of Water at the End of the Study

\begin{tabular}{|c|c|c|c|c|}
\hline \multirow{2}{*}{ Parameter } & \multicolumn{4}{|c|}{ Station } \\
\hline & 1 & 2 & 3 & 4 \\
\hline Temperature $\left({ }^{\circ} \mathrm{C}\right)$ & $27.80 \pm 0.50$ & $28.97 \pm 0.15$ & $28.57 \pm 0.06$ & $29.57 \pm 0.64$ \\
\hline Velocity $(\mathrm{m} / \mathrm{s})$ & $26.67 \pm 2.89$ & $26.67 \pm 2.89$ & $38.33 \pm 2.89$ & $33.33 \pm 5.77$ \\
\hline $\mathrm{DO}(\mathrm{mg} / \mathrm{L})$ & $7.29 \pm 0.23$ & $7.29 \pm 0.15$ & $7.17 \pm 0.10$ & $7.39 \pm 0.06$ \\
\hline $\mathrm{COD}(\mathrm{mg} / \mathrm{L})$ & $41.33 \pm 3.79$ & $41.33 \pm 0.58$ & $60.67 \pm 6.11$ & $50.67 \pm 6.11$ \\
\hline $\mathrm{BOD}(\mathrm{mg} / \mathrm{L})$ & $27.33 \pm 0.58$ & $27.33 \pm 3.06$ & $61.67 \pm 2.31$ & $66.33 \pm 2.08$ \\
\hline $\mathrm{pH}$ & $6.96 \pm 0.12$ & $6.96 \pm 0.11$ & $7.02 \pm 0.06$ & $6.92 \pm 0.04$ \\
\hline $\mathrm{Pb}$ (water) (mg/L) & $0.0203 \pm 0.0012$ & $0.0203 \pm 0.0006$ & $0.0157 \pm 0.0047$ & $0.0227 \pm 0.0012$ \\
\hline $\mathrm{Pb}$ (sediment) (mg/L) & $0.1097 \pm 0.0049$ & $0.1097 \pm 0.0061$ & $0.0733 \pm 0.0064$ & $0.0837 \pm 0.0031$ \\
\hline $\mathrm{Hg}$ (water) $(\mathrm{mg} / \mathrm{L})$ & $0.0067 \pm 0.0006$ & $0.0067 \pm 0.0015$ & $0.0067 \pm 0.0006$ & $0.0067 \pm 0.0006$ \\
\hline $\mathrm{Hg}$ (sediment) $(\mathrm{mg} / \mathrm{L})$ & $0.1377 \pm 0.0057$ & $0.1377 \pm 0.0080$ & $0.0983 \pm 0.0187$ & $0.1120 \pm 0.0123$ \\
\hline $\mathrm{Cd}($ water) $(\mathrm{mg} / \mathrm{L})$ & $0.0057 \pm 0.0006$ & $0.0057 \pm 0.001$ & $0.0053 \pm 0.0023$ & $0.0047 \pm 0.0012$ \\
\hline $\mathrm{Cd}($ sediment $)(\mathrm{mg} / \mathrm{L})$ & $0.0393 \pm 0.0046$ & $0.0393 \pm 0.0015$ & $0.0560 \pm 0.0035$ & $0.0600 \pm 0.0104$ \\
\hline
\end{tabular}

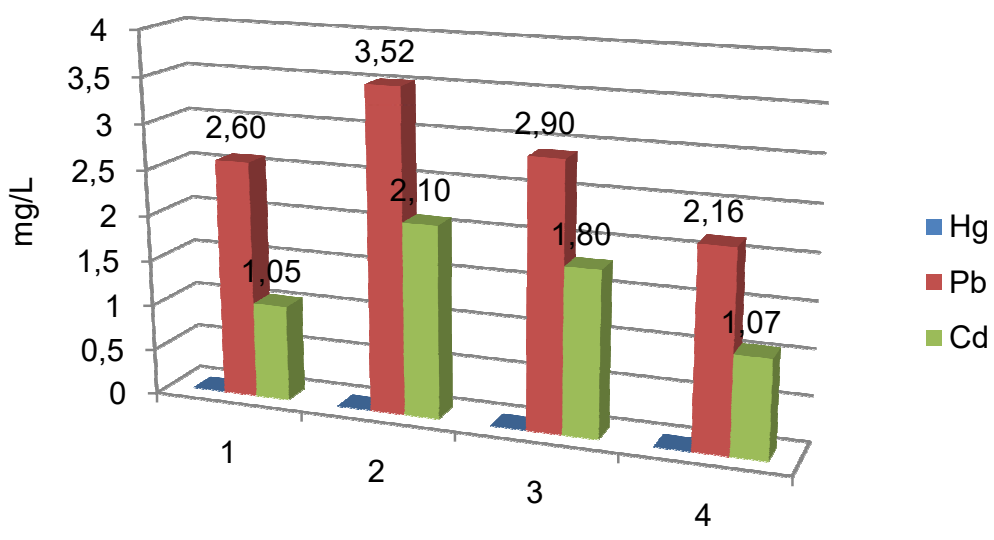

Figure 1 - Concentration of heavy metals on fish gills from the 4 stations 
The observation detected two heavy metals, $\mathrm{Pb}$ and $\mathrm{Cd}$, in the gill of the tilapia while $\mathrm{Hg}$ was not detected. $2.60 \mathrm{mg} / \mathrm{Kg}$ of $\mathrm{Pb}$ and $1.05 \mathrm{mg} / \mathrm{Kg}$ of $\mathrm{Cd}$ were found in station 1, 3.52 $\mathrm{mg} / \mathrm{kg}$ of $\mathrm{Pb}$ and $2.10 \mathrm{mg} / \mathrm{Kg}$ of Cd were found in station $2,2.90 \mathrm{mg} / \mathrm{kg}$ of $\mathrm{Pb}$ and $1.80 \mathrm{mg} / \mathrm{Kg}$ of $\mathrm{Cd}$ were found in station $3,2.16 \mathrm{mg} / \mathrm{kg}$ of $\mathrm{Pb}$ and $1.07 \mathrm{mg} / \mathrm{Kg}$ of Cd were found in station 4. The highest $\mathrm{Pb}$ and $\mathrm{Cd}$ concentration was detected in station 2 because industrial and domestic disposal from station 1 was flowing to the station (station 2). Stations 1 and 2 are located in a straight line without any barrier to flow of the water. $\mathrm{Pb}$ and $\mathrm{Cd}$ concentration decreased from station 3 and 4 because these two last stations are not in as straight line to the first two stations (station 1 and 2). It is predicted that the waste (heavy metals) is deposited in sinuous curves and bends of Sungai Wangi basin.

The amount of $\mathrm{Pb}$ is higher than that of Cd. According to Hutagalung (1990), the ability of biota (living organism) to accumulate heavy metals is probably influenced by several factors such as type of heavy metal, type or size of the organism, length of exposure, and environmental condition or water condition. The $\mathrm{Pb}$ and $\mathrm{Cd}$ were accumulated in the fish gills because gills were the first exposed organ and functioned to filter air and water. Darmono (2011) explained that gills are sensitive to $\mathrm{Pb}$ toxicity. It is predicted that heavy metals were accumulated in the gills without precipitating in the sediment. Absorption through gills flows into fish body and facilitates gas exchange and osmosis.

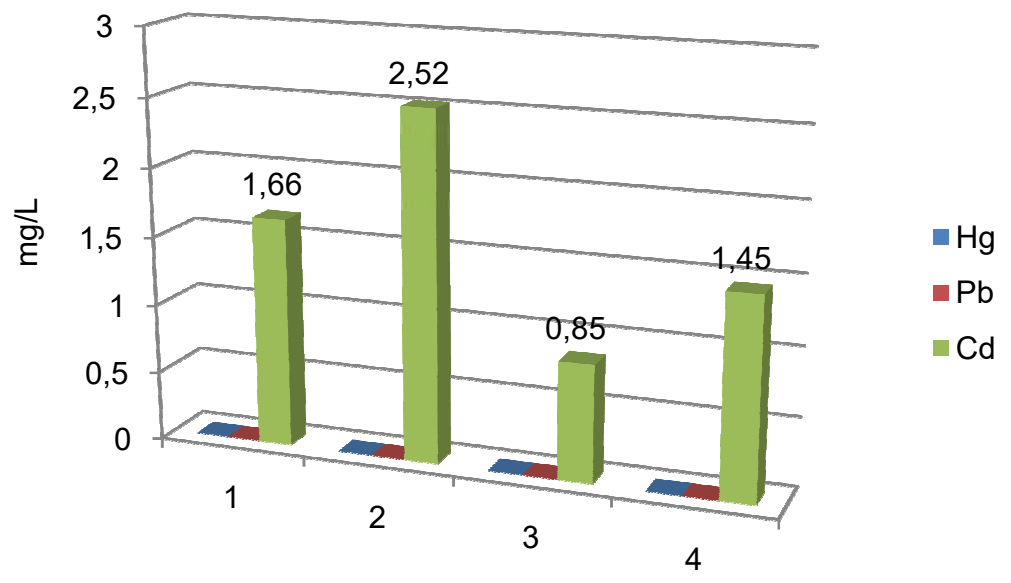

Figure 2 - Concentration of heavy metals in fish liver from the 4 stations

Type of heavy metal found in the fish liver is $\mathrm{Cd}$ or cadmium while either $\mathrm{Hg}$ or $\mathrm{Pb}$ was not detected. $1.66 \pm 0.02 \mathrm{mg} / \mathrm{Kg}$ of $\mathrm{Cd}$ was found in station $1,2.52 \pm 0.09 \mathrm{mg} / \mathrm{kg}$ of Cd was found in station 2, $0.85 \pm 0.1 \mathrm{mg} / \mathrm{kg}$ was found in station 3 and $1.45 \pm 0.02 \mathrm{mg} / \mathrm{kg}$ of Cd was found in station 4 . The researchers found higher $\mathrm{Cd}$ content of $\mathrm{Cd}$ in the fish liver than in the water. It showed that the metal can accumulate in the fish liver as the organ functions to filter toxic.

Heavy metal accumulation occurs because heavy metals tend to form complex compounds with organic substances the fish contains; thus, the heavy metal is fixed in the fish body instead of being excreted immediately. Fish liver metabolizes $\mathrm{Cd}$ and the metal is activated by enzymes in the fish liver. According to Linder (2006), heavy metal absorption in the digestive system is brought into the blood plasma, bound by new albumin and protein and carried to the liver, where it is incorporated into seruloplasmin and specific liver proteins or enzymes then excreted through the bile.

Micronuclei observation in station 1-4 showed that higher micronuclei means worse damage to erythrocyte cells taking place due to heavy metals. The figure above showed that station 2 had the highest micronuclei while station 4 had the lowest one. Station 2 had the highest micronuclei because all waste from agricultural, domestic and industrial activities is flowing to the station. Micronuclei is a change in cell nucleus due to failure in cell division. Mikronuclei are characterized by 2 separated cell nucleus in which one is smaller than the 
other. The smaller nucleus is oval or round-shaped and one-third to one-sixth smaller than the cell nucleus (Rajkokila, et al., 2010). Diameter of micronuclei is less than one-fifth of cell nucleus diameter, is close to the cell nucleus and has similar color intensity as the cell nucleus (Lusiyanti, et.al., 1996).

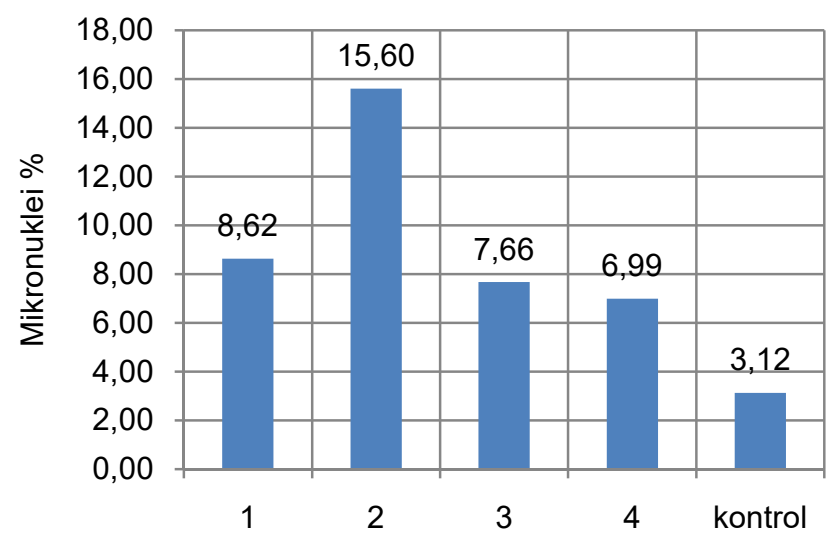

Figure 3 - Frequency of micronuclei in the fish exposed to Wangi River

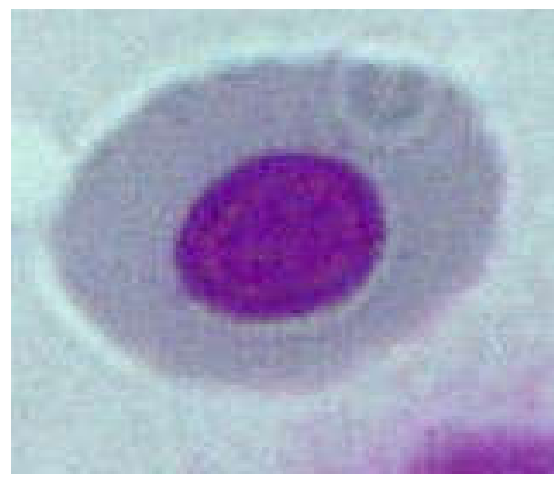

Figure 4 - Normal Erythrocyte Cell

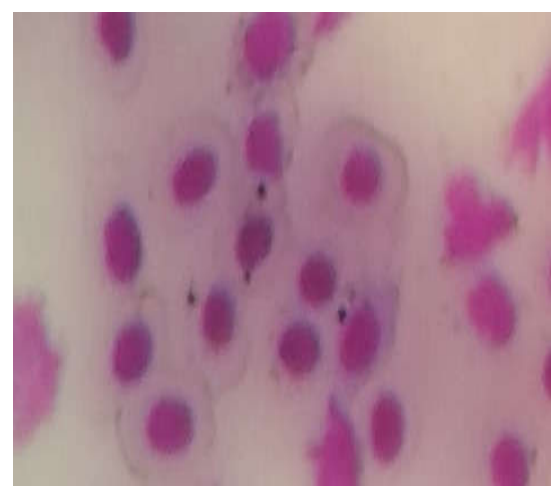

Figure 5 - Nuclear Budd

Micronuclei may be considered as cell of which nucleus is abnormal; some examples of abnormality in cell nucleus are berikut adalah bentuk abnormalitas seperti binucleated cell, karyorhetic cell, karyolytic cell, nuclear budd, and fragmented nucleus (Holland, et.al., 2008). The figure above showed micronuclei obtained from station 1. It showed some changes in the shape of micronuclei (cell is supposed to have 1 nucleus instead of 2 nuclei having different size). The damage is called nuclear budd because one cell has two separated nuclei and one nucleus is bigger than the other one. Nuclear budd occurs due to failure in cell division. 


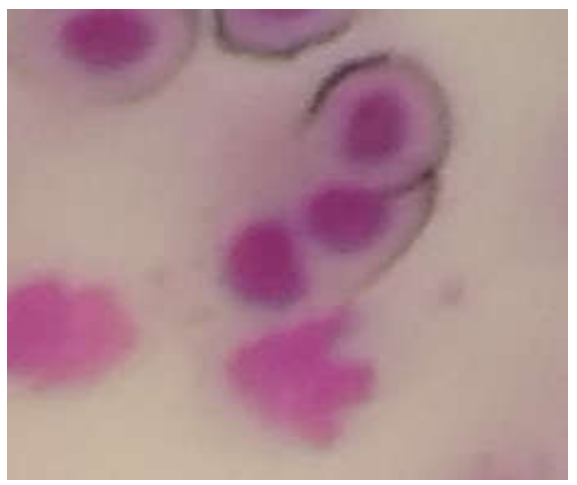

Figure 6 - Binucleated cell with 2 separated nuclei

Having observed station 1 (industrial area), the researchers were able to identify another type of nucleus damage called Binucleated cell, where a cell has two separated nuclei. Lusiyanti, et.al (1996) stated that micronuclei takes place due to pressure from ligand such as environment, microorganism or chemicals and as the result, chromatin fiber in the chromosome shrinks and develops micronuclei due to energy shortage. It is predicted that the heavy metals in Sungai Wangi contributed to the micronuclei development. Erythrocyte cells were unable to divide perfectly and therefore, the micronuclei are developed.

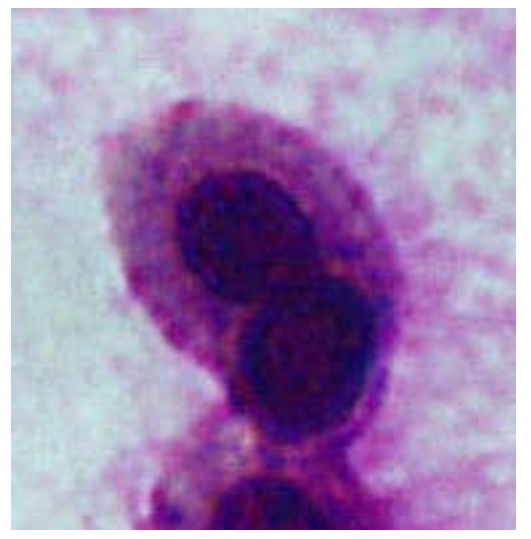

Figure 7 - Binucleated Cell

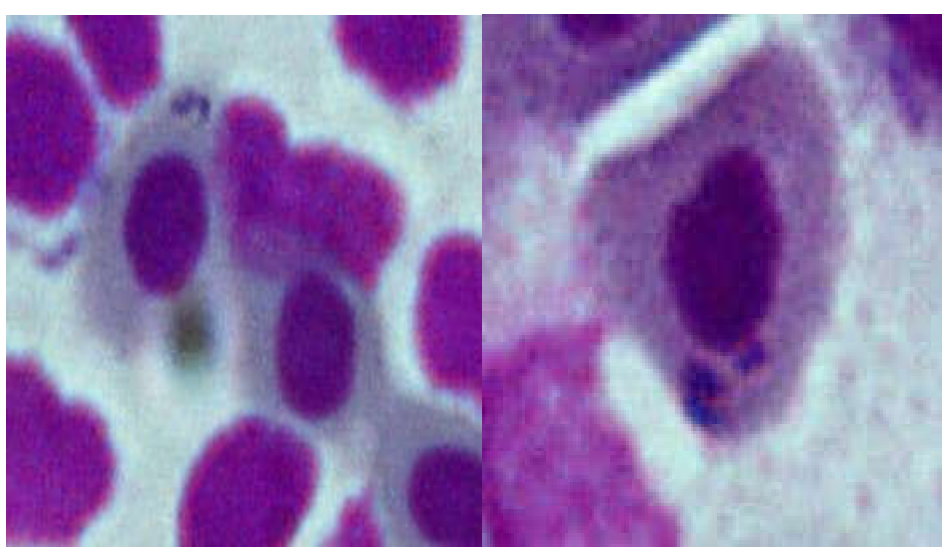

Figure 8 - Binucleated cell with nuclear blebs in Station 2 and 4

Figure 7 showed binucleated erythrocyte cell obtained from station 3 (residential area). Both cell nuclei were not separated completely due to failure in cell division. It showed that the water in station 1 is flowing to station 2 and 3 and as the result, stressor in station 1 and 2 would influence the water in station 3 . Binucleated cell took place due to cytokinesis failure affected by ligand stressor in the water. Micronuclei were developed from ascentric fragment 
or various chromosomal fractures. More aberration meant more micronuclei (number). Chromosomal aberration analysis can be conducted to cells in their metaphase stage only.

Figure 8 showed binucleated cell with nuclear blebs, another type of micronuclei. According to Zelazna, et.al (2011), the erythrocyte is the result of both aneugenic and clastogenic influence. Heavy metals may cause failure in cell division in which spindle fibers were unable to split. During anaphase stage, when elements started to move to the spindle fibers, chromatid center and chromosome fracture entered the lag phase. After telophase, intact chromosome fracture, for example nuclear fracture, produced small nucleus. Although cell division also took place in the other cell, most were transferred to one or more secondary nuclei, far smaller than the original nuclei and in general called micronukleus or micronuclei (Gangar, et.al. 2010).

\section{CONCLUSION}

The study reported that the level of $\mathrm{Pb}$ and $\mathrm{Cd}$ found in tilapia fish gills and liver has exceeded the normal threshold ( $\mathrm{Pb}$ in tilapia fish gills is between 2.10 and $3.52 \mathrm{mg} / \mathrm{L}$ while $\mathrm{Cd}$ in tilapia fish is $2.52 \mathrm{mg} / \mathrm{L}$ ). In addition, the percentage of micronuclei is between 3.12 and $15.60 \%$. At last, heavy metals resulted in various erythrocyte micronuclei damage such as nuclear budd and Binucleated cell (Binucleated cell with 2 separated nuclei and binucleated cell with nuclear blebs).

\section{REFERENCES}

1. Adam, M.A. \& Maftuch. 2015. Evaluasi pengoptimalan instansi pengolahan water limbah terhadap pencemaran sungai wangi di pasuruan. Journal of Environmental Engineering \& Sustainable Technology. 2(1):1-5

2. Darmono. 2010. Lingkungan Hidup dan Pencemaran (Hubungannya dengan Toksikologi Senyawa Logam). Jakarta: UI Press.

3. Holland, N., Bolognesi, C., Kirsch-Volders, M., Bonassi, S., Zeiger, E., Knasmueller, S., Fenech, M. 2008. The Micronucleus Assay In Human Buccal Cell as A Tool For Biomonitoring DNA Damage : The Human Project Perspective On Current Status and Knowledge Gaps. Elsevier, pp. 16-30.

4. Hutagalung, H.P. 1991. Pencemaran Laut Oleh Logam Berat. Puslitbang Oseanologi. Status Pencemaran Laut di Indonesia dan Teknik Pemantauannya. Jakarta: LIPI.

5. Javed, M., Ahmad, I., Usmani, N., \& Ahmad, M. 2016. Studies on Biomarkers of Oxidative Stress And Associated Genotoxicity and Histopathology in Channa punctatus From Heavy Metal Polluted Canal. Chemosphere. 151 : 210-219

6. Linder, M.C. 2006. Biokimia Nutrisi dan Metabolisme. Jakarta: UI-Press, pp. 265-278.

7. Lusiyanti, Y., Indrawati, I., Wa'id, A., Lubis, M. 1996. Studi Awal Mikronuklei Pada Sel Limfosit Perifer. Proceeding, Presentasi Ilmiah Keselamatan Radiasi dan Lingkungan BATAN, August 20-21, 1996, (8): 278-282

8. Rajkokila, K., Shajithanoop, S., Usrahani, M.V. 2010. Nuclear anomalies in exfoliated buccal epithelial cell of pectrol station attendants in Tamilnadu, South India. Journal Genetic and Genomics 2(2) : 18-22

9. Seriani, R. et al. 2015. Invitro mucus transportability, cytogenotoxicity, and hematological changes as non-destructive physiological biomarkers in fish chronically exposed to metals. Ecotoxicology and Environmental Safety. $112: 162-168$

10. Gangar, S.C., Sandhir, R., Koul, A. 2010. Anti-clastogenic activity of azadirachta indica against benzo(a)pyrene in murine forestomach tumorigenesis bioassay. Acta Poloniae Pharmaceutica - Drug Research, 67: 381-390.

11. Grant, K.R. 2015. Fish Hematology and Associated Disorders. Veterinary Clinics of North America Exotic Animal Practice. 18(1) : 681-701

12. Zelazna, K., Rudnicka, K., \& Tejs, S. (2011). Micronucleus test and PAHs. Environmental Biotechnology, 7: 70-80. 